\title{
A Difficult Endoscopic Third Ventriculostomy Procedure: Perforation of a Thick Liliequist Membrane with High Basilar Artery Location
}

\section{Zor Bir Endoskopik Üçüncü Ventrikülostomi Uygulamast: Yüksek Baziller Arter Yerleşimi ve Kalın Liliequist Membran Perforasyonu}

Ali Erdem YILDIRIM, Derya KARAOGLU, Denizhan DIVANLIOGLU, Ahmed Deniz BELEN

Ankara Numune Research and Education Hospital, Department of Neurosurgery, Ankara, Turkey

Corresponding Author: Ali Erdem YILDIRIM / E-mail: alierdemyildirim@gmail.com

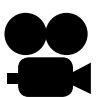

To watch the surgical videoclip, please visit http://turkishneurosurgery.org.tr/images/13135_video.mp4

\begin{abstract}
Endoscopic Third Ventriculostomy (ETV) is a minimally invasive and safe method used in the treatment of obstructive hydrocephalus. However, arterial bleeding episodes that arise from narrowing of the safe perforation area due to a higher location of the basilar artery (BA) may have tragic consequences. Liliequist membrane (LM) or other membranous structures located in the prepontine cistern also affect the success rates with ETV and complicate the procedure. We present herein a safe and successful perforation of the thick LM after retracting BA in a triventricular hydrocephalus case having a high BA protruding into the third ventricle. ETV is an effective and minimally invasive treatment modality in selected cases. Although some case-specific factors may affect the procedural success and feasibility, favorable and safe outcomes are certainly achievable by overcoming these obstacles with increasing experience.
\end{abstract}

KEYWORDS: Endoscopic third ventriculostomy, High basilar artery, Thick liliequist membrane

öz

Endoskopik Üçüncü Ventrikülostomi (EUV), obstrüktif hidrosefali tedavisinde kullanılan az girişimsel ve güvenilir bir cerrahi tedavi seçeneğidir. Ancak bazı olgularda yüksek baziller arter (BA) yerleşimi nedeni ile güvenli perforasyon alanının daralması ve oluşabilecek arteriyel kanamalar ürkütücü sonuçlar doğurabilir. Liliequist membranı (LM) veya prepontin sisterne yerleșmiş diğer membranöz yapılar da EUV'nin başarısını etkilemekte ve işlemi zorlaştırmaktadır. Biz de 3. ventrikül içerisine doğru prolabe olan yüksek yerleşimli BA ve kalın LM'si bulunan triventriküler hidrosefali olgusunda BA'nın ekarte edilerek kalın LM'nin güvenli ve başarılı bir şekilde perforasyonunu sunmaktayız. EUV, seçilmiş olgularda etkili minimal invaziv bir tedavi yöntemidir. Olguya bağlı bazı faktörler işlemin başarısını ve uygulanabilirliğini etkilese de artan tecrübe ile bu zorlukların aşılabileceği, güvenli ve istenilen iyi sonuçların alınabileceği gerçeği akılda tutulmalıdır.

ANAHTAR SÖZCÜKLER: Endoskopik üçüncü ventrikülostomi, Yüksek baziller arter, Kalın liliequist membranı

\section{INTRODUCTION}

Endoscopic Third Ventriculostomy (ETV) is a minimally invasive and effective modality used for the treatment of obstructive hydrocephalus. However, it is not free of complications, of which basilar artery (BA) injury is the most feared and devastating one (5).

The BA apex is usually located on the posterior half of the floor of the third ventricle (4). In addition, radiological examinations have shown that it is closely related to the mammillary bodies in $12 \%$ of cases while it touches or courses at a distance less than $1 \mathrm{~mm}$ to Tuber Cinereum (TC) in 10\% of cases, which complicates the ETV procedure $(4,5)$. One additional factor that complicates the ETV procedure and affects its success is the presence of Liliequist membrane (LM) or any other membranous structure located in the prepontine cistern $(2,3)$.

We present herein a difficult ETV procedure in which we safely and successfully perforated a thick LM after retracting BA in a triventricular hydrocephalus case having a thick LM and a high BA that protruded into the third ventricle, occupied the TC completely, and abolished the safe space.

\section{CASE REPORT}

A 47-year-old man presented with headache and difficulty in walking. Cranial magnetic resonance imaging (MRI) examination revealed a triventricular hydrocephalus, and a 


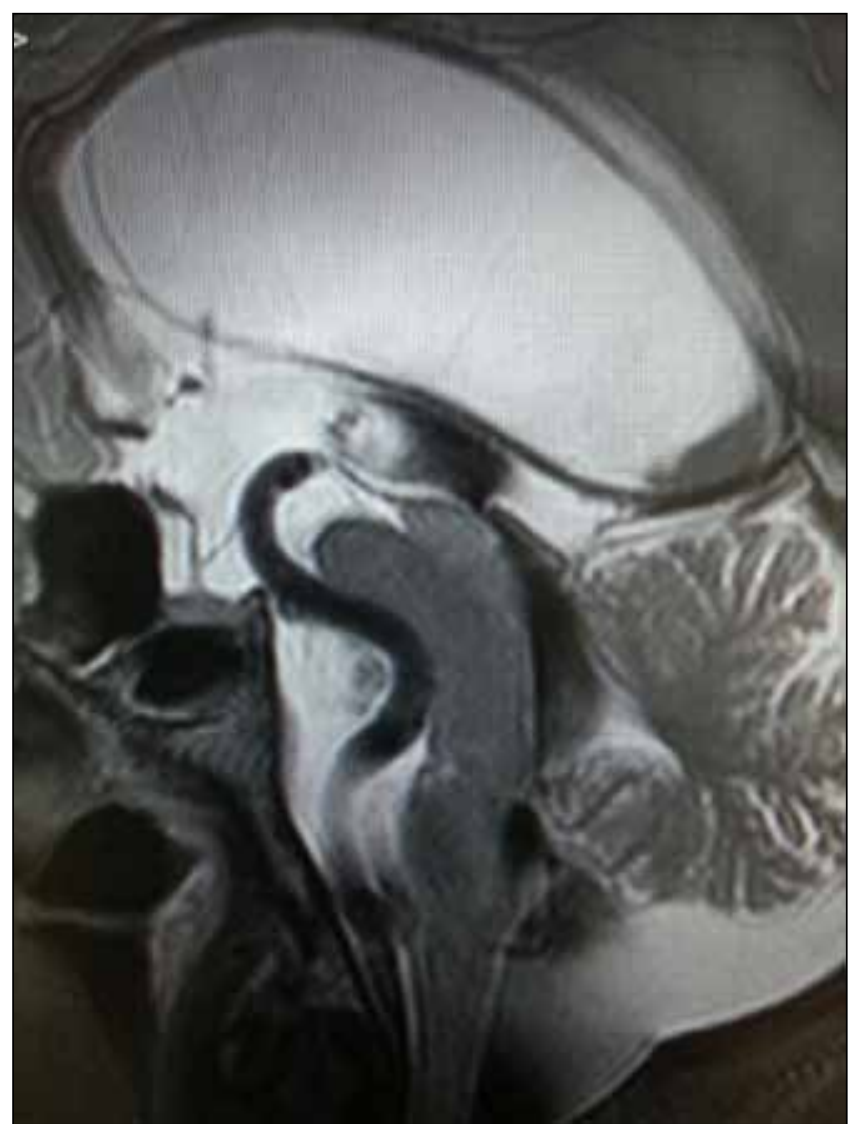

Figure 1: Cine phase MRI showing aqueductus stenosis, high location of basilar artery and thick Liliequist membrane.

Cine phase MRI showed aqueductus stenosis and an increased CSF flow rate. Additionally, there was a high location of BA (Figure 1). An ETV procedure was planned with these findings. The cranium was entered through the Kocher's point in the classical ETV position. Upon visual inspection, it was noted that the TC was completely covered by the apex of BA at the base of the third ventricle. The TC was then perforated from its anterior aspect, at a site close to the infundibulum. The incision was then deepened and the working cannula of the endoscope was used to retract the BA posteriorly. The thick LM was opened with the bipolar cautery and the procedure was successfully terminated without complications (video).
The patient had an uneventful hospital course and was discharged the third day after the operation. He had no headache at the time of discharge.

\section{DISCUSSION}

An important vascular complication of ETV involves injury to $B A$ and its perforating branches; the relationship of these structures with TC affects the risk of injury $(1,5)$. Furthermore, this relationship also affects the feasibility of ETV. The other factor that plays a role in the success rate of ETV is the presence of an LM or any other membranous structures located in the prepontine cistern (6). A successful ETV procedure also requires fenestration of these membranes (6). A high BA protruding into the third ventricle, concurrent with a thick $L M$, is a rare condition that reduces the success of the ETV procedure. We herein report a patient with this rare condition, in whom the BA was retracted with the working cannula and the thick LM was fenestrated. We suggest that BA variations, which are not that rare, are not a contraindication for the ETV procedure and successful outcomes are readily attainable in experienced hands.

\section{REFERENCES}

1. Abtin K, Thompson BG, Walker ML: Basilar artery perforation as a complication of endoscopic third ventriculostomy. PediatrNeurosurg 28: 35-41, 1998

2. Anık I, Ceylan S, Koc K, Anık Y, Etus V, Genc H: Membranous structures affecting the success of endoscopic third ventriculostomy in adult aqueductus sylvii stenosis. Minim Invasive Neurosurg 54: 68-74, 2011

3. Fushimi $Y$, Miki $Y$, Takahashi JA, Kikuta K, Hashimoto N, Hanakawa T, Fukuyama H, Togashi K: MR imaging of Liliequist's membrane. Radiat Med 24: 85-90, 2006

4. Hayashi N, Endo S, Hamada H, Shibata T, Fukuda O, Takaku A: Role of preoperative midsagittal magnetic resonance imaging in endoscopic third ventriculostomy. Minim Invasive Neurosurg 42: 79-82, 1999

5. Horsburgh A, Matys T, Kirollos RW, MassoudTF:Tuber cinereum proximity to critical major arteries: A morphometric imaging analysis relevant to endoscopic third ventriculostomy. Acta Neurochir 155: 891-900, 2013

6. Yadav YR, Parihar V, Pande S, Namdev H, Agarwal M: Endoscopic Third Venticulostomy. J Neurosci Rural Pract 3: 163-173, 2012 